\title{
Fabrication of Iron-based Oxygen Carriers on Various Supports for Chemical Looping Hydrogen Generation
}

\author{
Hsuan-Chih Wu, Young Ku, Yi-Syuan Huang, Niels Michiel Moed*
}

Department of Chemical Engineering, National Taiwan University of Science and Technology, Taipei 106, Taiwan

\begin{abstract}
$\mathrm{Fe}_{2} \mathrm{O}_{3} / \mathrm{Al}_{2} \mathrm{O}_{3}$ and $\mathrm{Fe}_{2} \mathrm{O}_{3} / \mathrm{TiO}_{2} / \mathrm{Al}_{2} \mathrm{O}_{3}$ oxygen carriers were fabricated and evaluated for chemical looping hydrogen generation (CLHG) using a TGA system and a fixed-bed reactor. Oxygen carriers were converted to around $33 \%$ in a fixed-bed reactor to ensure uniform reduction. The reduced oxygen carrier was tested for steam generation, where in all cases $\mathrm{Fe}_{2} \mathrm{O}_{3} / \mathrm{Al}_{2} \mathrm{O}_{3}$ displayed a better conversion than $\mathrm{Fe}_{2} \mathrm{O}_{3} / \mathrm{TiO}_{2} / \mathrm{Al}_{2} \mathrm{O}_{3}$. It was found that increasing the reaction temperature from 800 to $850^{\circ} \mathrm{C}$ had little effect for either oxygen carrier, but a further increase to $900^{\circ} \mathrm{C}$ resulted in an increased steam conversion. A higher steam flow rate caused a lower overall steam conversion but a higher $\mathrm{H}_{2}$ production. A higher feed rate of reduced oxygen carrier let to a higher steam conversion up to a rate of 18.4 and $14.9 \mathrm{~g} \mathrm{~min}^{-1}$ for $\mathrm{Fe}_{2} \mathrm{O}_{3} / \mathrm{Al}_{2} \mathrm{O}_{3}$ and $\mathrm{Fe}_{2} \mathrm{O}_{3} / \mathrm{TiO}_{2} / \mathrm{Al}_{2} \mathrm{O}_{3}$, respectively. A final comparison was performed with up to 50 redox cycles, where $\mathrm{Fe}_{2} \mathrm{O}_{3} / \mathrm{Al}_{2} \mathrm{O}_{3}$ showed superior reactivity in the first cycles but ended at a conversion of $54.6 \%$ with $\mathrm{Fe}_{2} \mathrm{O}_{3} / \mathrm{TiO}_{2} / \mathrm{Al}_{2} \mathrm{O}_{3}$ ending at a conversion of $64.6 \%$.
\end{abstract}

Keywords: Chemical looping hydrogen generation (CLHG), $\mathrm{Fe}_{2} \mathrm{O}_{3} / \mathrm{Al}_{2} \mathrm{O}_{3}, \mathrm{Fe}_{2} \mathrm{O}_{3} / \mathrm{TiO}_{2} / \mathrm{Al}_{2} \mathrm{O}_{3}$, Oxygen carrier, Moving-bed reactor

\section{INTRODUCTION}

Hydrogen is an environmentally friendly energy option which can address issues such as global climate change, air pollution and energy security. The ways to produce hydrogen are many, with the steam-iron process (SIP) being used since the early $20^{\text {th }}$ century (Hurst, 1939). In this process, iron species are employed to split water molecules by binding to the oxygen atoms, generating iron oxide and hydrogen. This process can be implemented in continuous reduction and oxidation cycles of the iron oxide. However, the reactivity of iron oxides is significantly reduced after repeated redox cycling, resulting in poor hydrogen generation (Kierzkowska et al., 2010). Iron oxides are also frequently employed as oxygen carrier in the chemical looping process (CLP) for efficient fuel combustion with generation of high concentration $\mathrm{CO}_{2}$. The integration of the steam-iron process with chemical looping, termed as chemical looping hydrogen generation (CLHG), generates high-purity $\mathrm{CO}_{2}$ and $\mathrm{H}_{2}$ simultaneously by using an Fe-based oxygen carrier operating in a moving-bed reactor (Tong et al., 2013).

Chemical looping hydrogen generation employs a fuel reactor for combustion of fuel and generation of $\mathrm{CO}_{2}$, a steam reactor for generation of $\mathrm{H}_{2}$ and an air reactor for further oxidation of the oxygen carrier. Fuels react with the oxygen carriers in the fuel reactor, with the product being a gas that is mainly composed of $\mathrm{CO}_{2}$ and $\mathrm{H}_{2} \mathrm{O}$. The reactions are expressed by the following Eqs. (1)-(2).

$\mathrm{C}_{n} \mathrm{H}_{2} m+(2 n+m) \mathrm{Fe}_{2} \mathrm{O}_{3} \rightarrow n \mathrm{CO}_{2}+m \mathrm{H}_{2} \mathrm{O}+(4 n+2 m) \mathrm{FeO}$

$3 \mathrm{C}_{n} \mathrm{H}_{2} m+(2 n+m) \mathrm{Fe}_{2} \mathrm{O}_{3} \rightarrow 3 n \mathrm{CO}_{2}+3 m \mathrm{H}_{2} \mathrm{O}+(4 n+2 m) \mathrm{Fe}$ 
$\mathrm{CO}_{2}$ can be purified from the gas stream through condensation of the water vapor. The reduced oxygen carriers are then oxidized by steam to generate hydrogen as demonstrated by Eqs. (3)-(4).

$3 \mathrm{FeO}+\mathrm{H}_{2} \mathrm{O} \rightarrow \mathrm{Fe}_{3} \mathrm{O}_{4}+\mathrm{H}_{2}$

$3 \mathrm{FeO}+4 \mathrm{H}_{2} \mathrm{O} \rightarrow \mathrm{Fe}_{3} \mathrm{O}_{4}+4 \mathrm{H}_{2}$

The partly oxidized Fe-based oxygen carriers are subsequently regenerated by further oxidation in the air reactor as illustrated by Eq. (5).

$4 \mathrm{Fe}_{3} \mathrm{O}_{4}+\mathrm{O}_{2} \rightarrow 6 \mathrm{Fe}_{2} \mathrm{O}_{3}$

Sintering and attrition during continuous and high temperature operations would decrease the effectiveness of these iron-based oxygen carriers. The reactivity and recyclability of iron-based oxygen carriers was reported to be considerably enhanced by coupling mixed metal oxides to prevent the sintering of oxygen carriers and to enhance their mechanical strength. A wide range of metal oxides can be utilized as support materials, such as $\mathrm{Al}_{2} \mathrm{O}_{3}, \mathrm{TiO}_{2}, \mathrm{ZrO}_{2}, \mathrm{SiO}_{2}$ and bentonite, each with their own advantages and disadvantages. $\mathrm{Fe}_{2} \mathrm{O}_{3}$ is commonly used with $\mathrm{Al}_{2} \mathrm{O}_{3}$ as a support material, where $\mathrm{Al}_{2} \mathrm{O}_{3}$ not only enhances the mechanical strength of $\mathrm{Fe}_{2} \mathrm{O}_{3}$ but also increases the reactivity. Cho et al. (2006), for example, mixed 60 wt\% $\mathrm{Fe}_{2} \mathrm{O}_{3}$ with 40 wt\% $\mathrm{Al}_{2} \mathrm{O}_{3}$ to fabricate the oxygen carriers by the freeze-granulation technique. Experimental results illustrated that the fabricated oxygen carriers delivered a high reduction and oxidation reactivity without noticeable carbon formation, as methane was used as fuel. Abad et al. (2007) utilized $\mathrm{Fe}_{2} \mathrm{O}_{3} / \mathrm{Al}_{2} \mathrm{O}_{3}$ oxygen carriers, fabricated with the same weight ratio by freeze granulation technique, in a continuous unit at temperatures from 800 to $950^{\circ} \mathrm{C}$. Experiments using natural gas or syngas were carried out for a total of 40 hours, without evident signs of deactivation, agglomeration, carbon deposition and with very low attrition for the fabricated oxygen carriers. Chiu et al. (2014) observed that $\mathrm{FeAl}_{2} \mathrm{O}_{4}$ is formed during $\mathrm{CLP}$ with $\mathrm{Fe}_{2} \mathrm{O}_{3}$ and $\mathrm{Al}_{2} \mathrm{O}_{3}$. This is still an effective oxygen carrier and possesses a higher melting point than $\mathrm{FeO}$, mitigating agglomeration of pellets.

$\mathrm{TiO}_{2}$ is another commonly used support metal oxide. Mattisson et al. (2004) fabricated various $\mathrm{Fe}_{2} \mathrm{O}_{3} / \mathrm{Al}_{2} \mathrm{O}_{3} / \mathrm{TiO}_{2}$ oxygen carriers, and the XRD patterns revealed that major reactions occurred between $\mathrm{Fe}_{2} \mathrm{O}_{3}$ and $\mathrm{TiO}_{2}$. The amounts of $\mathrm{Fe}_{2} \mathrm{O}_{3}$ and $\mathrm{TiO}_{2}$ affected the crush strength of the fabricated oxygen carriers, with oxygen carriers containing $60 \% \mathrm{Fe}_{2} \mathrm{O}_{3}$ outperforming those containing $40 \%$. Ilmenite, a titanium-iron-oxide mineral with the formula $\mathrm{FeTiO}_{3}$, was reported by Cuadrat et al. (2011) to be a reliable and effective oxygen carrier for the chemical looping combustion of coal and petroleum coke as solid fuels for energy production. Not only did this achieve high $\mathrm{CO}_{2}$ capture efficiencies, no noticeable decrease in the conversion of ilmenite was observed. Adánez et al. (2010) indicated that the reactivity of ilmenite stabilized after several redox operation cycles in a TGA system, which is possibly attributed to the increased porosity and the structural changes during the chemical looping operation. However, Zhao and Shadman (1990) noted that phase segregation of iron oxide and titanium oxide took place over multiple redox cycles. Iron oxide was observed to migrate out to the surface from the $\mathrm{FeTiO}_{3}$ during the oxidation, as shown by XRD analyses. This could fracture the ilmenite particles and lower the particle strength. $\mathrm{Fe}_{2} \mathrm{O}_{3} / \mathrm{Al}_{2} \mathrm{O}_{3}$ and $\mathrm{Fe}_{2} \mathrm{O}_{3} / \mathrm{TiO}_{2} / \mathrm{Al}_{2} \mathrm{O}_{3}$ oxygen carriers were fabricated and assessed by Lo (2014) for their applications in chemical looping combustion and chemical looping hydrogen generation. Both oxygen carriers demonstrated high effectivity and recyclability with an iron, titanium and aluminum ratio of 7:1:2 exhibiting excellent reduction over multiple cycles, possibly due to its high oxygen carrying capacity.

The objective of this paper is to investigate the feasibility and effectivity of the addition of $\mathrm{TiO}_{2}$ to $\mathrm{Fe}_{2} \mathrm{O}_{3} / \mathrm{Al}_{2} \mathrm{O}_{3}$ oxygen carriers for use in a CLHG system. To accomplish this comparison, oxygen carriers were fabricated and uniformly reduced in a fixed-bed reactor system. The reduced oxygen carriers were subsequently partially regenerated in a moving-bed reactor system using steam oxidation. Both freshly fabricated and regenerated oxygen carriers were tested in a TGA system over 50 cycles to test recyclability and long-term regeneration efficiency. 


\subsection{Preparation and TGA Reactivity Testing of Iron-based Oxygen Carriers}

$\mathrm{Fe}_{2} \mathrm{O}_{3} / \mathrm{Al}_{2} \mathrm{O}_{3}$ and $\mathrm{Fe}_{2} \mathrm{O}_{3} / \mathrm{TiO}_{2} / \mathrm{Al}_{2} \mathrm{O}_{3}$ were fabricated to serve as oxygen carriers in this study. Hematite, alumina and titania particles were mixed thoroughly in deionized water at room temperature. The $\mathrm{Fe}_{2} \mathrm{O}_{3} / \mathrm{Al}_{2} \mathrm{O}_{3}$ oxygen carriers were formulated with $60 \%$ hematite $\left(99.9 \% \mathrm{Fe}_{2} \mathrm{O}_{3}\right.$, China Steel) and $40 \%$ alumina ( $99 \% \mathrm{Al}_{2} \mathrm{O}_{3}$, Chin Jung) while the $\mathrm{Fe}_{2} \mathrm{O}_{3} / \mathrm{TiO}_{2} / \mathrm{Al}_{2} \mathrm{O}_{3}$ was formulated with $70 \%$ hematite, $20 \%$ alumina and $10 \%$ titania $\left(99 \% \mathrm{TiO}_{2}\right.$, Unique Enterprise Co.). The wellmixed slurry was desiccated at $130^{\circ} \mathrm{C}$ for 12 hours and subsequently pulverized and screened for particles to a size between 1.2 and $1.4 \mathrm{~mm}$. The particles were afterward sintered for 2 hours in a muffle furnace at $1200^{\circ} \mathrm{C}$ for $\mathrm{Fe}_{2} \mathrm{O}_{3} / \mathrm{TiO}_{2} / \mathrm{Al}_{2} \mathrm{O}_{3}$ and at $1300^{\circ} \mathrm{C}$ for $\mathrm{Fe}_{2} \mathrm{O}_{3} / \mathrm{Al}_{2} \mathrm{O}_{3}$, which were the optimum sintering temperatures according to Lo (2014). The surface of the fabricated oxygen carriers was subsequently characterized using a D2 PhASER X-Ray Diffractor by Bruker and a JSM6500F Field Emission Scanning Electron Microscope (FE-SEM) by JOEL.

The reactivity of fabricated oxygen carriers was analyzed by a Netzsch STA 449F3 thermogravimetric analyzer (TGA). A portion of $200 \mathrm{mg}$ oxygen carriers was loaded in an alumina crucible of the TGA, the temperature of the TGA chamber was elevated with a ramping rate of $30{ }^{\circ} \mathrm{C} \mathrm{min}^{-1}$ in air atmosphere and eventually kept at $900^{\circ} \mathrm{C}$. Residual air in the TGA chamber was purged by nitrogen for 5 minutes before $200 \mathrm{~mL} \mathrm{~min}^{-1}$ syngas (composed of $10 \% \mathrm{CO}, 10 \% \mathrm{H}_{2}$ and $80 \% \mathrm{~N}_{2}$ ) was introduced into the TGA chamber for reducing the fabricated oxygen carriers. After the oxygen carriers were reduced, $200 \mathrm{~mL} \mathrm{~min}^{-1}$ air was then introduced to oxidize the reduced oxygen carriers. The reduction and oxidation procedure was replicated for up to 50 cycles to determine the recyclability of fabricated iron-based oxygen carriers.

\subsection{Reduction Tests Using the Fixed-bed Reactor System}

Reduction in the Fixed-Bed Reactor System was tested, with the goal of reducing oxygen carriers by $33 \%$ for further use in following tests. The fixed-bed reactor system consisted of a stainless-steel tubular reactor with a PID-controlled heating element. A plate with sixteen $0.25 \mathrm{~mm}$ apertures was located in the lower part of the reactor for supporting fabricated iron-based oxygen carriers. Oxygen carriers were added to the system, where the mass added was adjusted for particle density. The temperature of the loaded reactor was then raised and eventually kept at the chosen operating temperature, which was originally $650^{\circ} \mathrm{C}$ but was raised to $800^{\circ} \mathrm{C}$ for $\mathrm{Fe}_{2} \mathrm{O}_{3} / \mathrm{Al}_{2} \mathrm{O}_{3}$, as this oxygen carrier could not be sufficiently reduced at $650^{\circ} \mathrm{C}$. A hydrogen/nitrogen gas mixture was subsequently introduced into the fixed-bed reactor to reduce fabricated oxygen carriers. The outlet gas stream from the fixed-bed reactor was passed through a cold trap to condense water vapor, and was then analyzed by a gas chromatograph equipped with a thermal conductivity detector (GC-TCD, China Chromatography 2000) to determine the concentrations of hydrogen and nitrogen. The remaining reduced $\mathrm{Fe}_{2} \mathrm{O}_{3} / \mathrm{Al}_{2} \mathrm{O}_{3}$ and $\mathrm{Fe}_{2} \mathrm{O}_{3} / \mathrm{Al}_{2} \mathrm{O}_{3} / \mathrm{TiO}_{2}$ oxygen carriers were collected for further experiments carried out in the moving-bed reactor system.

\subsection{Reaction Tests in the Moving-Bed Reactor System}

A schematic diagram of the moving-bed reactor employed in this study is shown in Fig. 1. The reactor was composed of a stainless-steel tube covered with a PID-controlled electric heating element. The temperature inside the $60 \mathrm{~cm}$ reactor tube was measured at 3 points, located at 10, 30 and $50 \mathrm{~cm}$ from either the gas inlet or gas outlet. Roughly $2.5 \mathrm{~kg}$ reduced $\mathrm{Fe}_{2} \mathrm{O}_{3} / \mathrm{Al}_{2} \mathrm{O}_{3}$ and $2.1 \mathrm{~kg}$ reduced $\mathrm{Fe}_{2} \mathrm{O}_{3} / \mathrm{Al}_{2} \mathrm{O}_{3} / \mathrm{TiO}_{2}$ oxygen carriers collected from the fixed-bed reactor system were packed in the reactor before operation. In addition, reduced oxygen carriers were continuously fed into the packed moving-bed reactor by a screw conveyer after the reactor was heated up to predetermined temperatures. Steam and nitrogen were correspondingly introduced into the reactor for oxidizing the reduced oxygen carriers to generate hydrogen. The partially oxidized oxygen carriers were collectively removed out of the reactor by another screw conveyor. The outlet gas stream from the moving-bed reactor was cooled by a cold trap to condense water vapor and analyzed by a GC-TCD (China Chromatography 2000) to detect the concentration of hydrogen. 


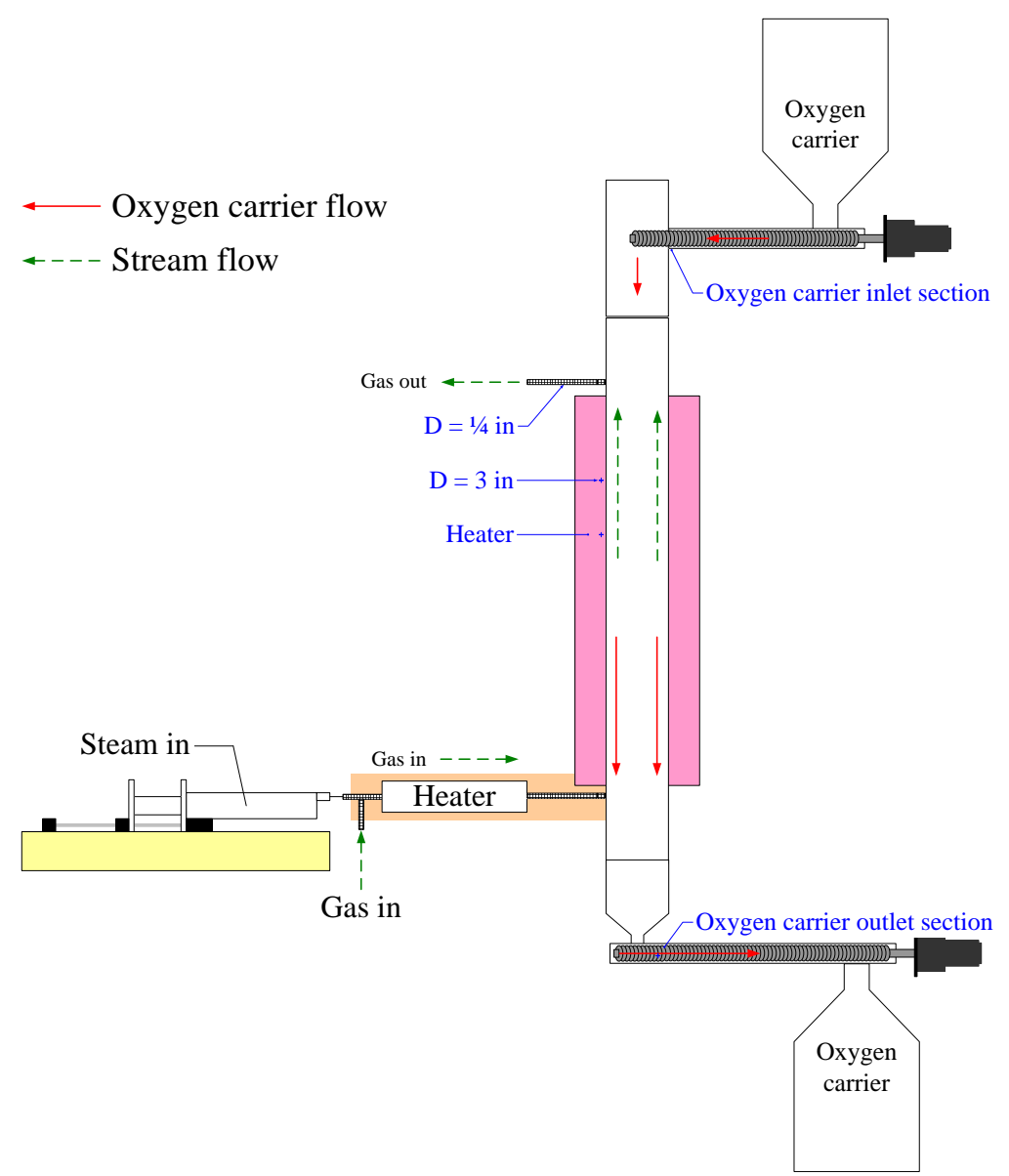

Fig. 1. Schematic diagram of the moving-bed reactor system used in this study.

\section{RESULTS AND DISCUSSION}

\subsection{Conversions of Fabricated Iron-based Oxygen Carriers}

The reactivity of fabricated $\mathrm{Fe}_{2} \mathrm{O}_{3} / \mathrm{Al}_{2} \mathrm{O}_{3}$ and $\mathrm{Fe}_{2} \mathrm{O}_{3} / \mathrm{TiO}_{2} / \mathrm{Al}_{2} \mathrm{O}_{3}$ oxygen carriers were examined in a TGA using syngas as reducing gas for 50 successive redox cycles. As depicted in Fig. 2, the reduction of $\mathrm{Fe}_{2} \mathrm{O}_{3} / \mathrm{Al}_{2} \mathrm{O}_{3}$ was about $68 \%$ initially and gradually decreased to $51 \%$ after 50 cycles. The reduction of $\mathrm{Fe}_{2} \mathrm{O}_{3} / \mathrm{TiO}_{2} / \mathrm{Al}_{2} \mathrm{O}_{3}$ increased slightly in the first 3 cycles and further after about 30 cycles after which it was maintained at around $60 \%$ up to the end of the 50 -cycle operation. This indicates that the fabricated iron-based oxygen carriers are capable of providing reasonable recyclability for continuous redox operation of syngas chemical looping combustion.

Based on the oxygen balance, the conversion of fabricated oxygen carriers $\left(X_{O C}\right)$ is defined as:

$X_{O C}=\frac{\int\left(F_{\mathrm{H}_{2}, \text { in }}-F_{\mathrm{H}_{2}, \text { out }}\right) d t}{3 N_{\mathrm{Fe}_{2} \mathrm{O}_{3}}}$

where the Fe fraction of oxygen carriers is reduced as follows:

$$
\begin{aligned}
& \mathrm{Fe}_{2} \mathrm{O}_{3}+\frac{1}{2} \mathrm{H}_{2} \rightarrow \frac{2}{3} \mathrm{Fe}_{3} \mathrm{O}_{4}+\frac{1}{2} \mathrm{H}_{2} \mathrm{O} \\
& \mathrm{Fe}_{3} \mathrm{O}_{4}+\mathrm{H}_{2} \leftrightarrow 3 \mathrm{FeO}+\mathrm{H}_{2} \mathrm{O} \\
& \mathrm{FeO}+\mathrm{H}_{2} \leftrightarrow \mathrm{Fe}+\mathrm{H}_{2} \mathrm{O}
\end{aligned}
$$




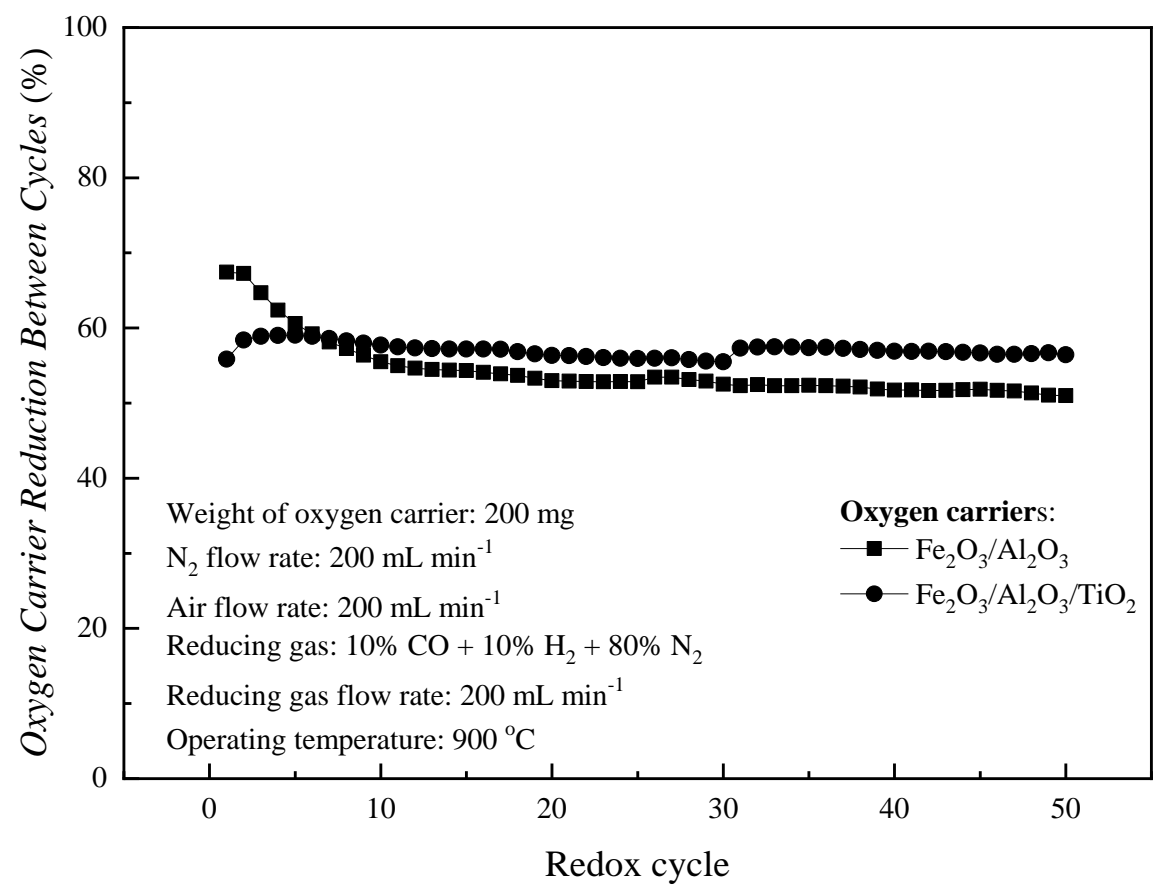

Fig. 2. Conversion of fabricated iron-based oxygen carriers employed in a TGA for 50 redox cycles at $900^{\circ} \mathrm{C}$.

Fig. 3 displays the reduction of fabricated $\mathrm{Fe}_{2} \mathrm{O}_{3} / \mathrm{TiO}_{2}$ and $\mathrm{Fe}_{2} \mathrm{O}_{3} / \mathrm{TiO}_{2} / \mathrm{Al}_{2} \mathrm{O}_{3}$ oxygen carriers in the fixed-bed reactor, with $\mathrm{Fe}_{2} \mathrm{O}_{3} / \mathrm{TiO}_{2} / \mathrm{Al}_{2} \mathrm{O}_{3}$ oxygen carriers reaching about $33 \%$ reduction after the introduction of the hydrogen/nitrogen gas mixture for 140 minutes at a temperature of $650^{\circ} \mathrm{C}$, corresponding to the oxygen utilization by hydrogen via the reduction of $\mathrm{Fe}_{2} \mathrm{O}_{3}$ to form $\mathrm{FeO}$ (Fan, 2010). However, the reduction of fabricated $\mathrm{Fe}_{2} \mathrm{O}_{3} / \mathrm{Al}_{2} \mathrm{O}_{3}$ conducted at $650^{\circ} \mathrm{C}$ was observed to reach only about $23 \%$ conversion after a 90 -minute operation, much lower than that for $\mathrm{Fe}_{2} \mathrm{O}_{3} / \mathrm{TiO}_{2} / \mathrm{Al}_{2} \mathrm{O}_{3}$. Higher conversion (approximately 33\%) was achieved for the reduction of fabricated $\mathrm{Fe}_{2} \mathrm{O}_{3} / \mathrm{Al}_{2} \mathrm{O}_{3}$ oxygen carriers operated at $800^{\circ} \mathrm{C}$ for operation time greater than 150 minutes. The higher reduction from $\mathrm{TiO}_{2}$ addition has been discussed by Li et al. (2011), who stated that while the addition of $\mathrm{TiO}_{2}$ does not seem to significantly reduce the activation energy for reduction, it does significantly lower the energy barrier for $\mathrm{O}^{2-}$ migration within the dense solid phase, enhancing the $\mathrm{O}^{2-}$ diffusivity.

\subsection{Hydrogen Generation in the Moving-Bed System with Reduced $\mathrm{Fe}_{2} \mathrm{O}_{3} / \mathrm{Al}_{2} \mathrm{O}_{3}$ Oxygen Carriers}

For experiments regarding to the chemical looping hydrogen generation by the reaction between steam and reduced iron-based oxygen carriers, the hydrogen yield $\left(X_{S}\right)$ is calculated as:

$X_{S}=\frac{F_{\mathrm{H}_{2}, \text { out }}}{F_{\mathrm{H}_{2} \mathrm{O}, \text { in }}}$

where $F_{\mathrm{H}_{2} \mathrm{O} \text {,in }}$ is the input molar flow rate $\left(\mathrm{mmole} \mathrm{min}^{-1}\right)$ of steam; $F_{\mathrm{H}_{2} \text {, out }}$ is the output molar flow rate $\left(m m o l e ~ \mathrm{~min}^{-1}\right.$ ) of hydrogen. CLHG experiments were performed with $\mathrm{Fe}_{2} \mathrm{O}_{3} / \mathrm{Al}_{2} \mathrm{O}_{3}$ oxygen carriers at a temperature range of $800-900^{\circ} \mathrm{C}$. As shown in Fig. 4, steam conversion was similar at 800 and $850^{\circ} \mathrm{C}$ but slightly increased for experiments conducted at $900^{\circ} \mathrm{C}$. Sun et al. (2015) examined the hydrogen conversion in a CLHG system with various oxygen carriers consisting of $\mathrm{Fe}_{2} \mathrm{O}_{3}, \mathrm{CeO}_{2}$ and $\mathrm{Al}_{2} \mathrm{O}_{3}$. They stated that hydrogen yield was doubled and even tripled when increasing the $\mathrm{Fe}_{2} \mathrm{O}_{3}$ content of oxygen carriers from $45 \%$ to $55 \%$ and $65 \%$, respectively, at an operating temperature of $900^{\circ} \mathrm{C}$. The effect of operating temperature on hydrogen production was found to be insignificant within the range of 850 to $950^{\circ} \mathrm{C}$, with hydrogen yield and steam 


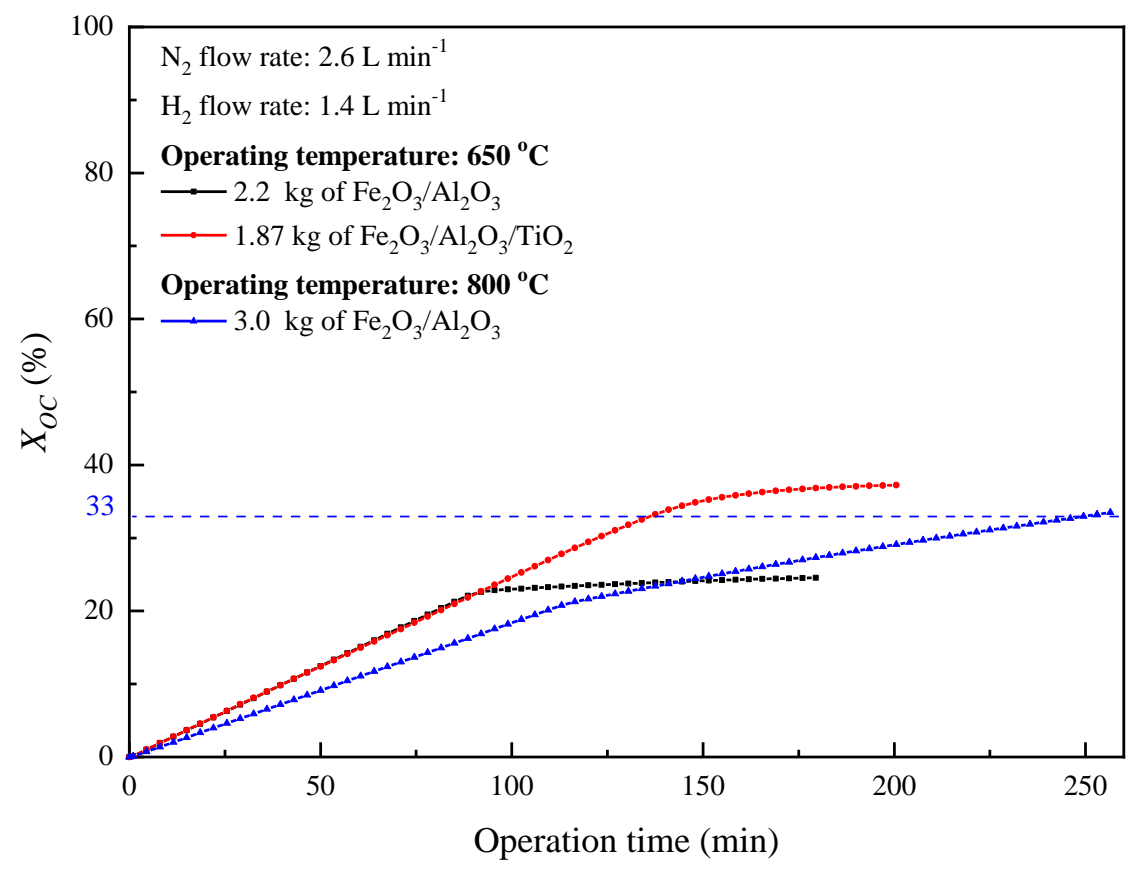

Fig. 3. Conversions of various fabricated iron-based oxygen carriers reduced by hydrogen in the fixed-bed reactor at $650^{\circ} \mathrm{C}$ and $800^{\circ} \mathrm{C}$.

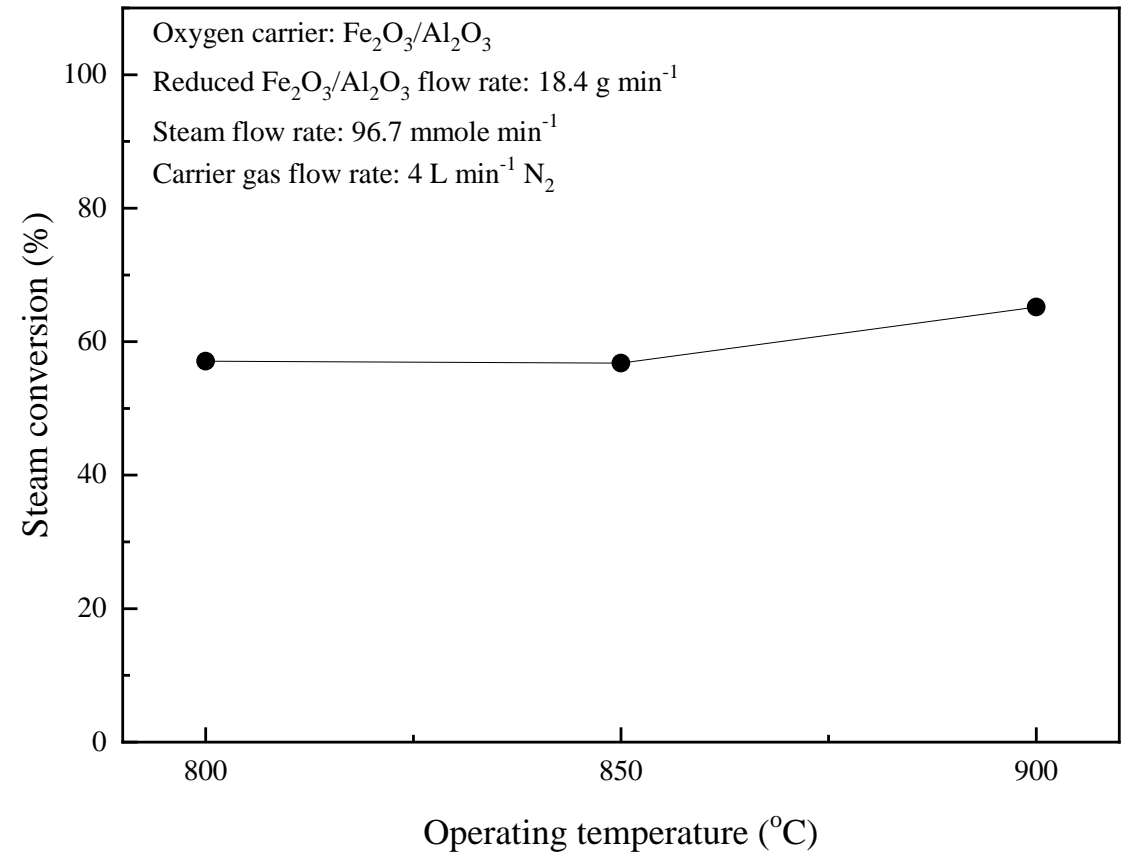

Fig. 4. Effect of operation temperature on the hydrogen flow rate, hydrogen concentration and steam conversion for $\mathrm{CLHG}$ with reduced $\mathrm{Fe}_{2} \mathrm{O}_{3} / \mathrm{Al}_{2} \mathrm{O}_{3}$ operated in the moving-bed reactor.

conversion increasing with temperature up until $900^{\circ} \mathrm{C}$ but decreased at $950^{\circ} \mathrm{C}$. This increase is comparable to the results observed in this study. The steam conversion by the reduced $\mathrm{Fe}_{2} \mathrm{O}_{3} / \mathrm{Al}_{2} \mathrm{O}_{3}$ oxygen carriers was noticed to be slightly enhanced with operating temperature, which was calculated to be about $65 \%$ for experiments conducted at $900^{\circ} \mathrm{C}$.

Chemical looping hydrogen generation by reduced $\mathrm{Fe}_{2} \mathrm{O}_{3} / \mathrm{Al}_{2} \mathrm{O}_{3}$ oxygen carriers with steam at $900^{\circ} \mathrm{C}$ were performed at various steam flow rates. As illustrated in Fig. 5, both hydrogen concentration and flow rate were evidently enhanced for experiments conducted at higher steam 


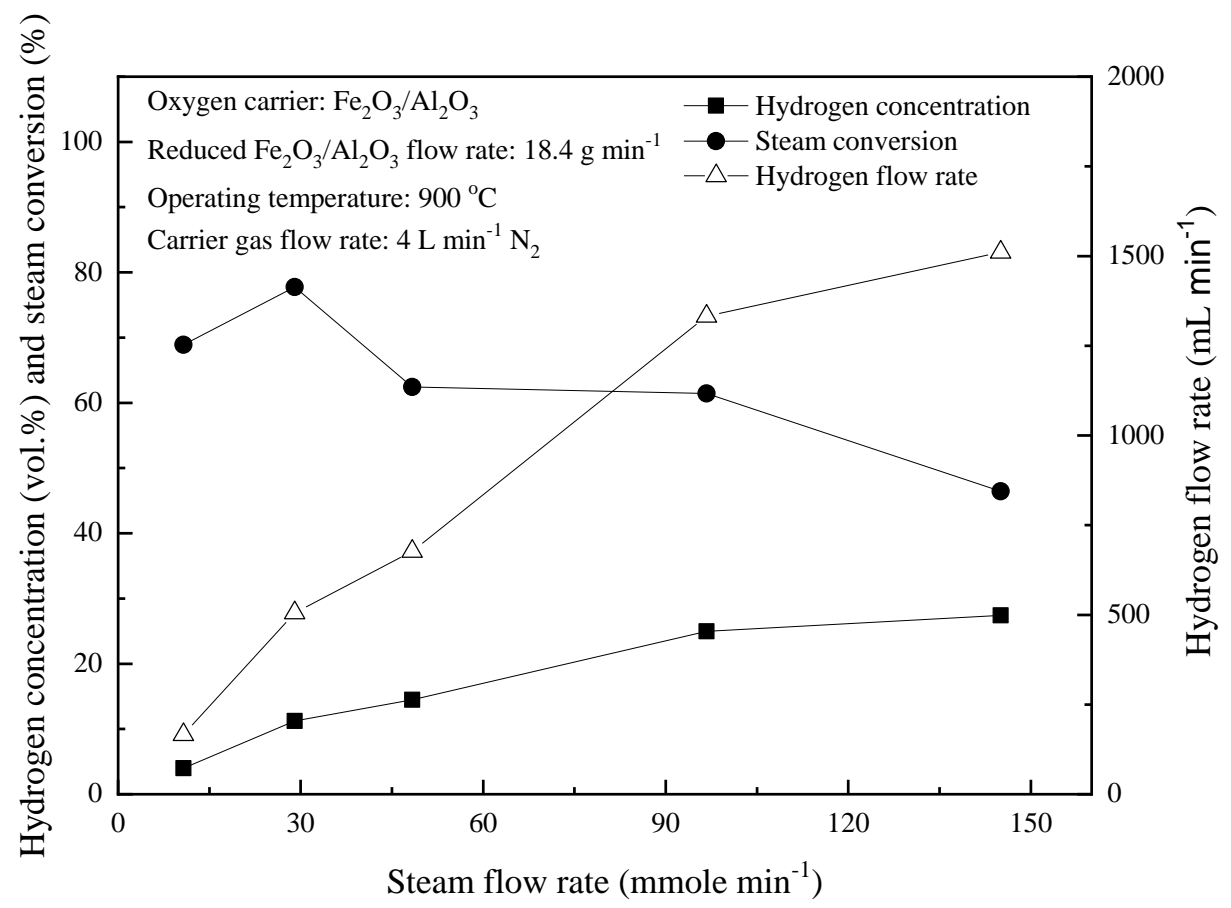

Fig. 5. Effect of steam flow rate on the hydrogen flow rate, hydrogen concentration and steam conversion for $\mathrm{CLHG}$ with reduced $\mathrm{Fe}_{2} \mathrm{O}_{3} / \mathrm{Al}_{2} \mathrm{O}_{3}$ operated in the moving-bed reactor.

flow rates, whereas the calculated steam conversions were decreased. The hydrogen flow rate of around $1.4 \mathrm{~L} \mathrm{~min}^{-1}$ was achieved with a steam flow rate of $96.7 \mathrm{mmole}^{-1}$, which led to a steam conversion of around $60 \%$. Lo (2014) also stated that experiments using $\mathrm{Fe}_{2} \mathrm{O}_{3} / \mathrm{TiO}_{2}$ oxygen carriers operated at higher steam flow rates might exhibit accelerated oxidation of $\mathrm{FeO}$ and $\mathrm{Fe}$ to $\mathrm{Fe}_{3} \mathrm{O}_{4}$, while hydrogen generation and steam conversion was reduced for experiments. Yang et al. (2008) demonstrated that the conversion of steam by iron is limited by the oxidation state of the iron and the steam flow rate in the steam reactor, where operations with more steam enhances the oxidation of iron and the production of hydrogen. Therefore, from an operating perspective, if hydrogen yield is the target, a higher steam flow rate is optimal within the described range. The same is true for hydrogen concentration. The lowered steam conversion efficiency, however, will lead to an increase in operating cost. This will lead to a consideration having to be made between operating cost and yield, which will depend on the specific operating system.

As shown in Fig. 6, both hydrogen concentration and flow rate were significantly increased for experiments conducted at a reduced $\mathrm{Fe}_{2} \mathrm{O}_{3} / \mathrm{Al}_{2} \mathrm{O}_{3}$ feeding rate lower than $18.4 \mathrm{~g} \mathrm{~min}^{-1}$. However, hydrogen concentration remained at about $26 \%$ for experiments conducted at a feeding rate of reduced $\mathrm{Fe}_{2} \mathrm{O}_{3} / \mathrm{Al}_{2} \mathrm{O}_{3}$ higher than $18.4 \mathrm{~g} \mathrm{~min}^{-1}$. Approximately $65 \%$ of steam conversion was achieved for experiments conducted with a feeding rate of reduced $\mathrm{Fe}_{2} \mathrm{O}_{3} / \mathrm{Al}_{2} \mathrm{O}_{3}$ higher than $18.4 \mathrm{~g} \mathrm{~min}^{-1}$. A similar observation was reported by previous researchers, (Yang et al., 2008) where steam conversion was increased for experiments conducted at higher feeding rate of reduced oxygen, until a certain steam conversion was reached.

XRD analysis for the fresh, reduced and partially oxidized $\mathrm{Fe}_{2} \mathrm{O}_{3} / \mathrm{Al}_{2} \mathrm{O}_{3}$ oxygen carriers are demonstrated in Fig. 7. The fresh oxygen carrier was determined to be completely comprised of $\mathrm{Fe}_{2} \mathrm{O}_{3}$ and $\mathrm{Al}_{2} \mathrm{O}_{3}$. The partial oxidation was conducted through steam reduction in the moving bed reactor at $900^{\circ} \mathrm{C}$ at an oxygen carrier flow rate of $18.4 \mathrm{~g} \mathrm{~min}^{-1}$ and a steam flow rate of $96.7 \mathrm{mmole} \mathrm{min}^{-1}$. $\mathrm{Fe}_{2} \mathrm{O}_{3}$ was transformed to $\mathrm{FeO}, \mathrm{Fe}_{3} \mathrm{O}_{4}$, and $\mathrm{Fe}$ after reduction while $\mathrm{Al}_{2} \mathrm{O}_{3}$ remained largely present, with some $\mathrm{FeAl}_{2} \mathrm{O}_{4}$ being formed. This observation was somewhat different from the results described by Cabello et al. (2014), noting that $\mathrm{FeAl}_{2} \mathrm{O}_{4}$ was the only stable Fe-based phase after reduction. After partial oxidation in the steam reactor, the previously formed Fe and FeO were observed to be oxidized primarily to $\mathrm{Fe}_{3} \mathrm{O}_{4}$. 


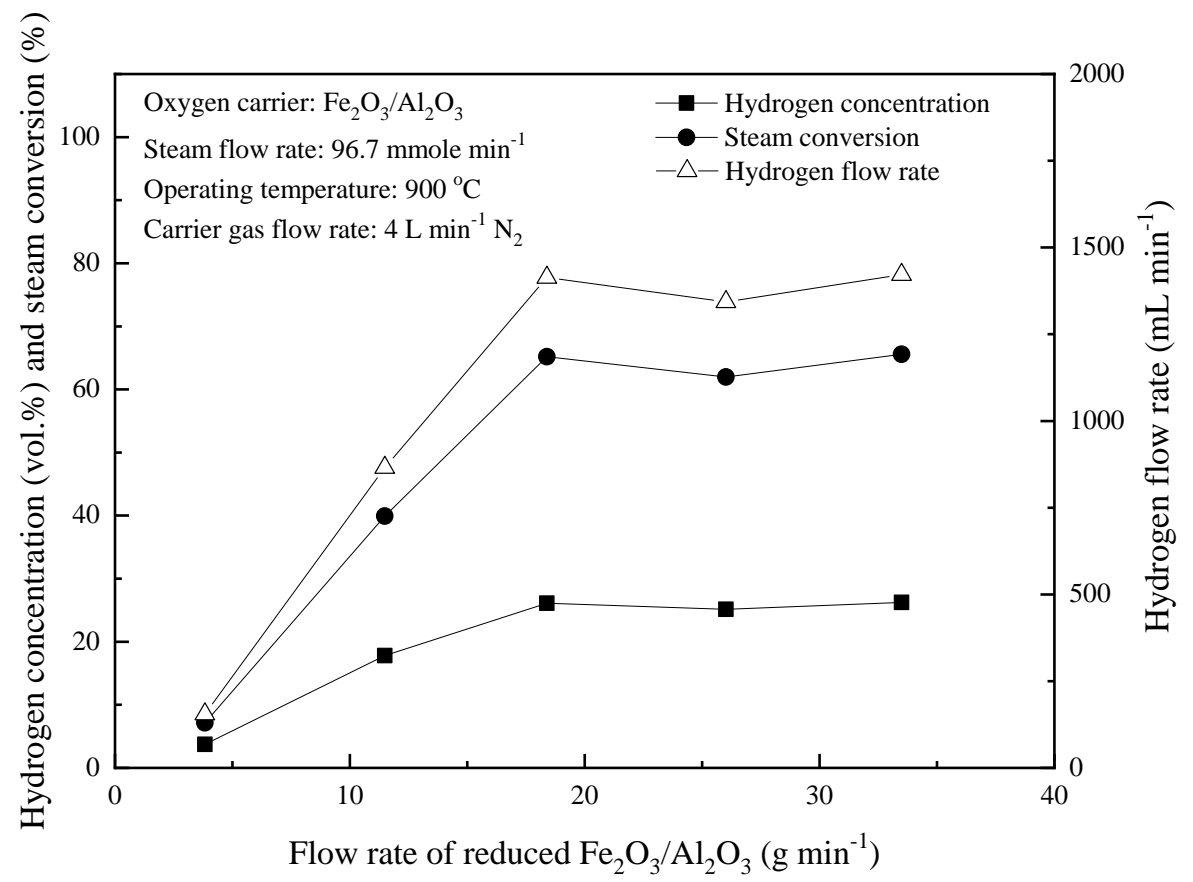

Fig. 6. Effect of oxygen carrier feeding rate on the hydrogen flow rate, hydrogen concentration and steam conversion for $\mathrm{CLHG}$ with reduced $\mathrm{Fe}_{2} \mathrm{O}_{3} / \mathrm{Al}_{2} \mathrm{O}_{3}$ operated in the moving-bed reactor.

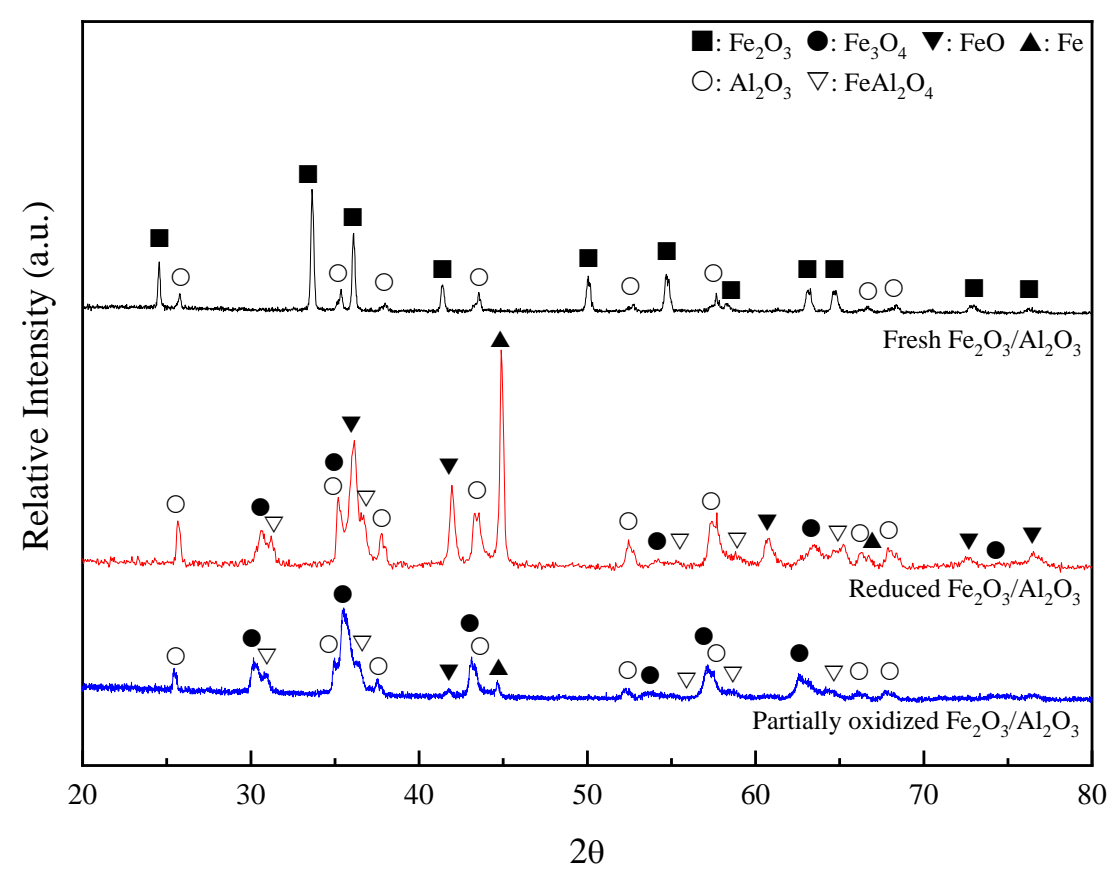

Fig. 7. X-ray diffraction patterns of fresh, reduced and partially oxidized $\mathrm{Fe}_{2} \mathrm{O}_{3} / \mathrm{Al}_{2} \mathrm{O}_{3}$ oxygen carriers employed for CLHG.

\subsection{Hydrogen Generation in the Moving-bed System with Reduced $\mathrm{Fe}_{2} \mathrm{O}_{3} / \mathrm{TiO}_{2} / \mathrm{Al}_{2} \mathrm{O}_{3}$ Oxygen Carriers}

Chemical looping hydrogen generation by reduced $\mathrm{Fe}_{2} \mathrm{O}_{3} / \mathrm{TiO}_{2} / \mathrm{Al}_{2} \mathrm{O}_{3}$ with steam was conducted in the moving-bed reactor operated at 800,850 and $900^{\circ} \mathrm{C}$. As illustrated in Fig. 8, steam conversion

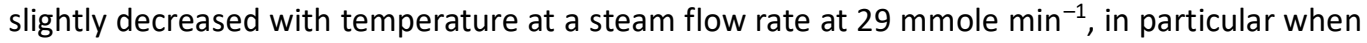
increasing the temperature from 800 to $850^{\circ} \mathrm{C}$ These results are not consistent with those 


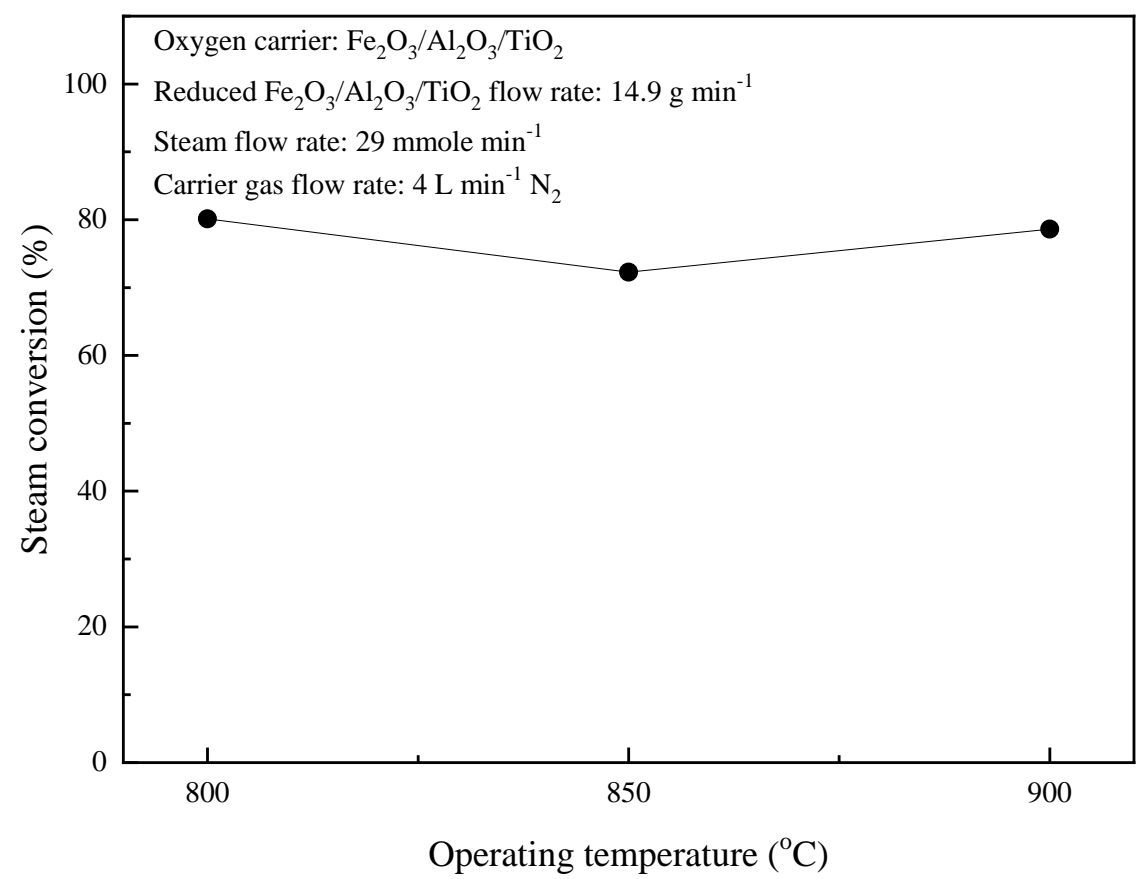

Fig. 8. Effect of operation temperature on the hydrogen flow rate, hydrogen concentration and steam conversion for $\mathrm{CLHG}$ with reduced $\mathrm{Fe}_{2} \mathrm{O}_{3} / \mathrm{Al}_{2} \mathrm{O}_{3} / \mathrm{TiO}_{2}$.

observed in Fig. 4 using $\mathrm{Fe}_{2} \mathrm{O}_{3} / \mathrm{Al}_{2} \mathrm{O}_{3}$ and those reported by Sun et al. (2015), which both exhibited an increase in hydrogen yield for reactions operated at elevated temperatures. Sun et al. (2015), however, did find a decrease in hydrogen yield and steam conversion when increasing their reaction temperature from $900-950^{\circ} \mathrm{C}$. The temperature at which this takes place likely depends on the materials used to fabricate oxygen carriers, in this case the $\mathrm{TiO}_{2}$ not being used by Sun et al. (2015) and in experiments shown in Fig. 4.

As demonstrated in Fig. 9, the hydrogen concentration and flow rate of the outlet gas stream increased with the steam flow rate, whereas steam conversion was decreased for experiments conducted with $\mathrm{Fe}_{2} \mathrm{O}_{3} / \mathrm{TiO}_{2} / \mathrm{Al}_{2} \mathrm{O}_{3}$. The concentration of hydrogen in the outlet gas stream was increased from about 12 to $22 \%$ when the steam flow rate was increased from 29 to $97 \mathrm{mmole} \mathrm{min}^{-1}$. A hydrogen flow rate of nearly $1.2 \mathrm{~L} \mathrm{~min}^{-1}$ was maintained for experiments conducted with a

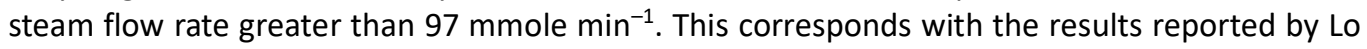
(2014), which showed that steam conversion was reduced for experiments conducted at higher steam flow rates by $\mathrm{Fe}_{2} \mathrm{O}_{3} / \mathrm{TiO}$ oxygen carriers. From an operating perspective, a higher steam flow rate increases hydrogen concentration and flow rate, leading to higher yields, within the tested range. But as mentioned in Fig. 5, the increased steam flow rate increased operating costs so that optimization will have to be done for the individual system to determine the optimal tradeoff between cost and yield.

As demonstrated in Fig. 10, the hydrogen concentrations of the outlet gas stream were found to be increased with greater oxygen carrier flow rate for experiments carried out with reduced $\mathrm{Fe}_{2} \mathrm{O}_{3} / \mathrm{TiO}_{2} / \mathrm{Al}_{2} \mathrm{O}_{3}$ flow rate up to $14.9 \mathrm{~g} \mathrm{~min}^{-1}$. At higher flow rates steam conversion was maintained at around $78 \%$ with a hydrogen flow rate of about $0.5 \mathrm{~L} \mathrm{~min}^{-1}$. The effect of oxygen carrier flow rate for experiments conducted with reduced $\mathrm{Fe}_{2} \mathrm{O}_{3} / \mathrm{TiO}_{2} / \mathrm{Al}_{2} \mathrm{O}_{3}$ are comparable to those conducted with reduced $\mathrm{Fe}_{2} \mathrm{O}_{3} / \mathrm{Al}_{2} \mathrm{O}_{3}$, as illustrated in Fig. 6.

XRD analysis was performed for the fresh, reduced and partially oxidized $\mathrm{Fe}_{2} \mathrm{O}_{3} / \mathrm{TiO}_{2} / \mathrm{Al}_{2} \mathrm{O}_{3}$ oxygen carriers, as shown in Fig. 11. Comparing the XRD patterns shown in Fig. 7 for $\mathrm{Fe}_{2} \mathrm{O}_{3} / \mathrm{Al}_{2} \mathrm{O}_{3}$, $\mathrm{Fe}_{2} \mathrm{O}_{3}$ was reduced to $\mathrm{Fe}_{3} \mathrm{O}_{4}$, and $\mathrm{Fe}$, with no FeO being detected. Zieliński et al. (2010) found that in the three-step reduction of $\mathrm{Fe}_{2} \mathrm{O}_{3}$ with $\mathrm{H}_{2}$ as a fuel gas, the final step of $\mathrm{FeO}$ to Fe can be so fast that $\mathrm{FeO}$ is not detected by XRD. They found that the rate of this reduction depends on the ratio of $\mathrm{H}_{2}$ fuel gas to the $\mathrm{H}_{2} \mathrm{O}$ formed in the reaction, with $\mathrm{FeO}$ being immediately reduced at low $\mathrm{H}_{2} \mathrm{O}$ and high $\mathrm{H}_{2}$ concentrations. After partial oxidation the Al species were completely 


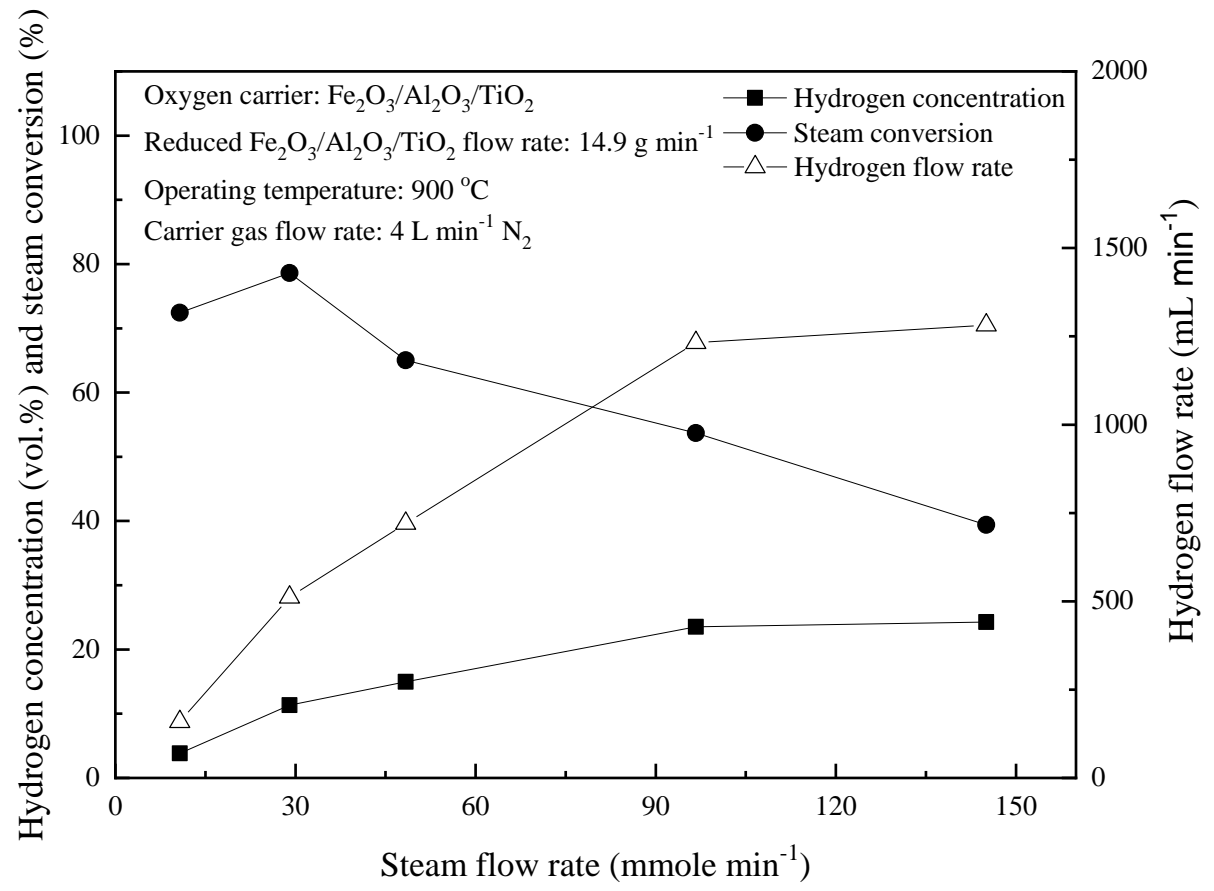

Fig. 9. Effect of steam flow rate on the hydrogen flow rate, hydrogen concentration and steam conversion for $\mathrm{CLHG}$ with reduced $\mathrm{Fe}_{2} \mathrm{O}_{3} / \mathrm{Al}_{2} \mathrm{O}_{3} / \mathrm{TiO}_{2}$.

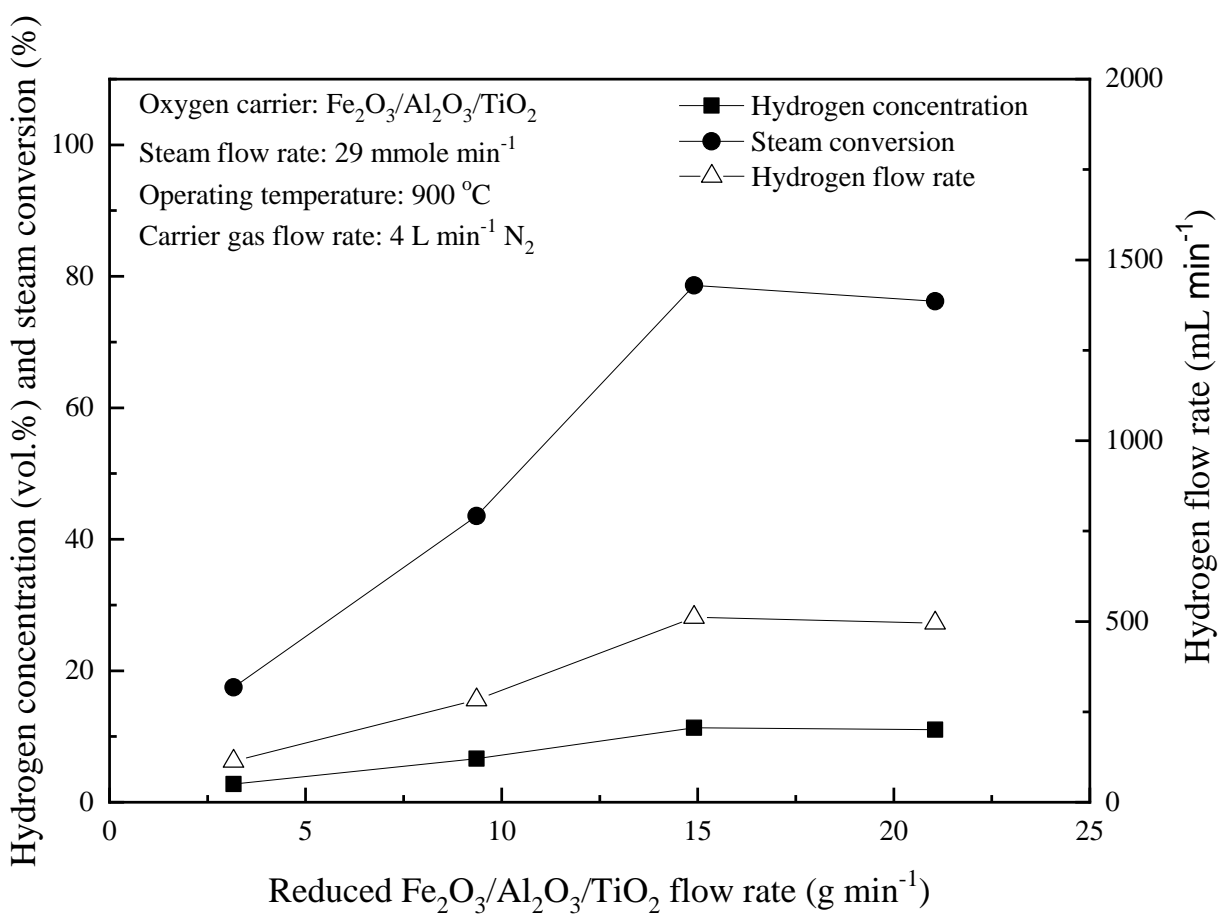

Fig. 10. Effect of oxygen carrier feeding rate on the hydrogen flow rate, hydrogen concentration and steam conversion for $\mathrm{CLHG}$ with reduced $\mathrm{Fe}_{2} \mathrm{O}_{3} / \mathrm{Al}_{2} \mathrm{O}_{3} / \mathrm{TiO}_{2}$.

oxidized to $\mathrm{FeAl}_{2} \mathrm{O}_{4}$, while in Fig. 7 it exists as both $\mathrm{Al}_{2} \mathrm{O}_{3}$ and $\mathrm{FeAl}_{2} \mathrm{O}_{4}$. This is likely due to influence of the lower $\mathrm{Al}$ fraction in $\mathrm{Fe}_{2} \mathrm{O}_{3} / \mathrm{TiO}_{2} / \mathrm{Al}_{2} \mathrm{O}_{3}$, as $\mathrm{Al}_{2} \mathrm{O}_{3}$ made up only $20 \%$ of the composition for $\mathrm{Fe}_{2} \mathrm{O}_{3} / \mathrm{TiO}_{2} / \mathrm{Al}_{2} \mathrm{O}_{3}$, instead of $40 \%$ for $\mathrm{Fe}_{2} \mathrm{O}_{3} / \mathrm{Al}_{2} \mathrm{O}_{3}$. Titanium was present as $\mathrm{Fe}_{2} \mathrm{TiO}_{5}$ in the fresh $\mathrm{Fe}_{2} \mathrm{O}_{3} / \mathrm{TiO}_{2} / \mathrm{Al}_{2} \mathrm{O}_{3}$ and was transformed to $\mathrm{Fe}_{2} \mathrm{TiO}_{4}$ after reduction. However, titanium species were not observed in the XRD pattern for the partially oxidized oxygen carrier, with the previously 


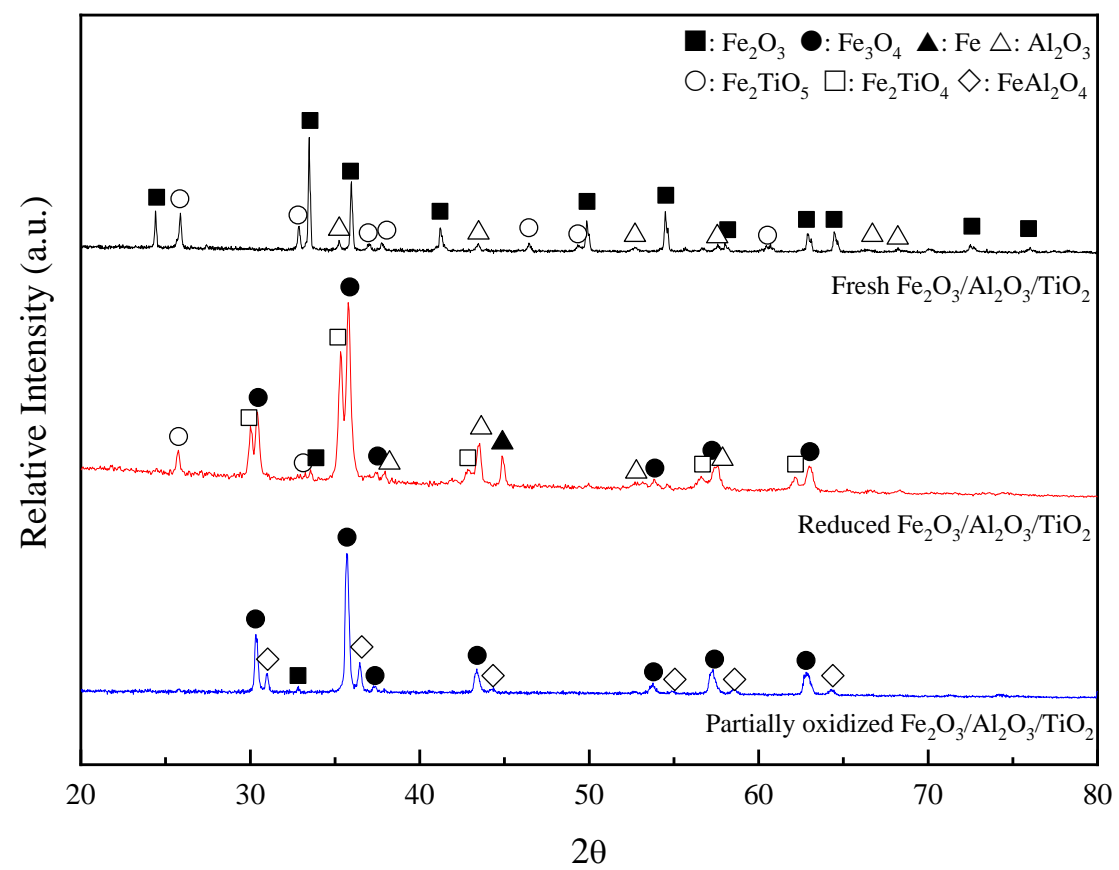

Fig. 11. X-ray diffraction patterns of fresh, reduced and partially oxidized $\mathrm{Fe}_{2} \mathrm{O}_{3} / \mathrm{Al}_{2} \mathrm{O}_{3} / \mathrm{TiO}_{2}$ oxygen carriers.

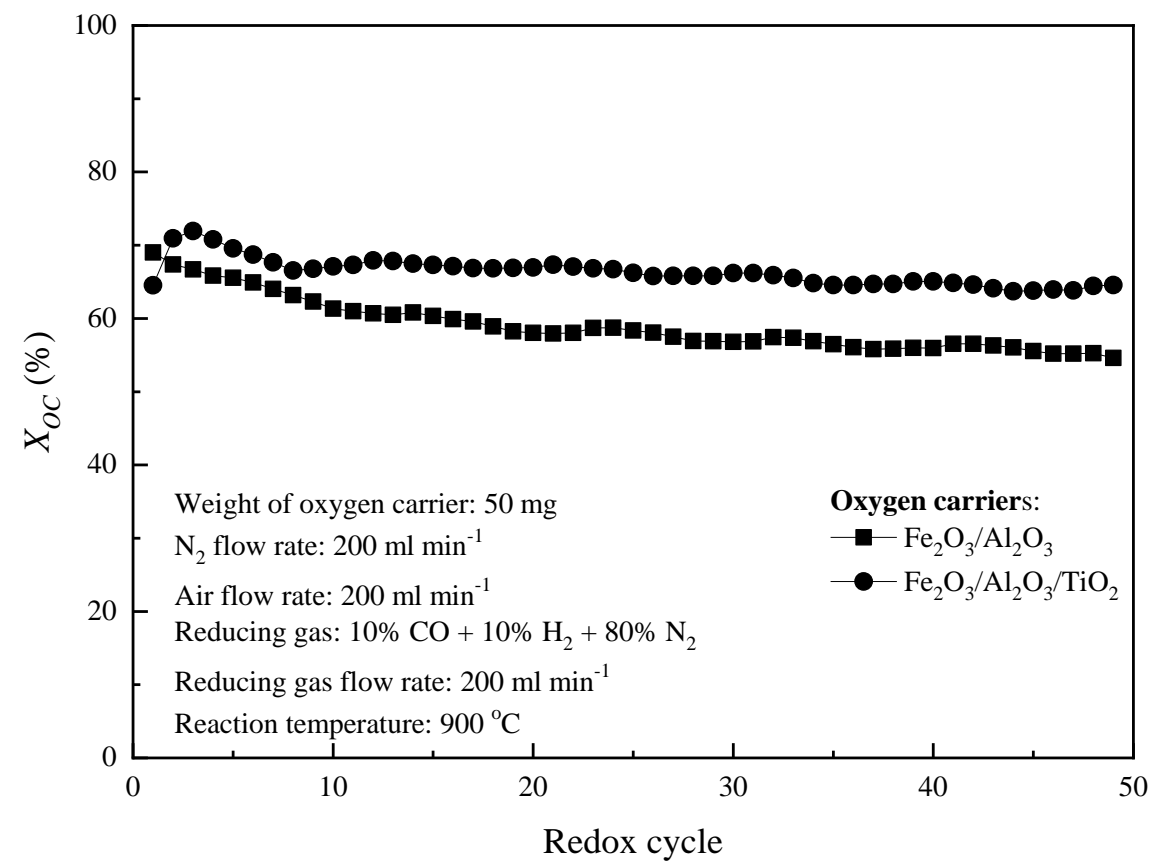

Fig. 12. Oxygen carrier conversions of regenerated oxygen carriers with syngas conducted in the TGA at $900^{\circ} \mathrm{C}$.

reduced iron and aluminum species being oxidized to $\mathrm{Fe}_{3} \mathrm{O}_{4}$ and $\mathrm{FeAl}_{2} \mathrm{O}_{4}$. This was also observed by previous researchers (Zhao and Shadman, 1990), where phase separation took place during the reduction of $\mathrm{Fe}_{2} \mathrm{O}_{3}$ and $\mathrm{TiO}_{2}$, with iron species moving out to the outer surface in a thermodynamically driven process.

Finally, the reactivity of regenerated oxygen carriers was examined using syngas as the reducing gas in TGA for 50 successive redox cycles. As depicted in Fig. 12, the conversions of $\mathrm{Fe}_{2} \mathrm{O}_{3} / \mathrm{Al}_{2} \mathrm{O}_{3}$ and $\mathrm{Fe}_{2} \mathrm{O}_{3} / \mathrm{TiO}_{2} / \mathrm{Al}_{2} \mathrm{O}_{3}$ remained at about 55 and $65 \%$, respectively, after 50 redox 
cycles. Comparing this to Fig. 2, displaying TGA results of freshly fabricated oxygen carriers using the same parameters, shows some interesting patterns. After 50 cycles, $\mathrm{Fe}_{2} \mathrm{O}_{3} / \mathrm{Al}_{2} \mathrm{O}_{3}$ oxygen carrier conversion was shown to be $51.0 \%$ with fresh oxygen carriers and $54.6 \%$ after regeneration. For $\mathrm{Fe}_{2} \mathrm{O}_{3} / \mathrm{TiO}_{2} / \mathrm{Al}_{2} \mathrm{O}_{3}$ this was 56.4 and $64.6 \%$ with fresh and regenerated oxygen carrier, respectively. This indicates that the regenerated oxygen carriers could provide reasonable reactivity and recyclability for continuous redox cycling with syngas combustion, with $\mathrm{Fe}_{2} \mathrm{O}_{3} / \mathrm{TiO}_{2} / \mathrm{Al}_{2} \mathrm{O}_{3}$ oxygen carriers displaying a higher benefit from regeneration.

\section{CONCLUSIONS}

Chemical looping hydrogen generation was performed using fabricated $\mathrm{Fe}_{2} \mathrm{O}_{3} / \mathrm{Al}_{2} \mathrm{O}_{3}$ and $\mathrm{Fe}_{2} \mathrm{O}_{3} / \mathrm{TiO}_{2} / \mathrm{Al}_{2} \mathrm{O}_{3}$ oxygen carriers. Initial TGA tests revealed that conversion at $900^{\circ} \mathrm{C}$ was very comparable between oxygen carriers, remaining between 50 and $55 \%$. The oxygen carriers were reduced to $33 \%$ inside a fixed-bed reactor for further steam conversion experiments. For steam regeneration inside a moving-bed reactor an increase in temperature from 800 to $850^{\circ} \mathrm{C}$ caused no significant increase but a further increase to $900^{\circ} \mathrm{C}$ led to an increased steam conversion. A higher steam flow rate generally led to higher hydrogen concentrations and flow rates but lower overall steam conversions. $\mathrm{Fe}_{2} \mathrm{O}_{3} / \mathrm{Al}_{2} \mathrm{O}_{3}$ oxygen carriers displayed a higher $\mathrm{H}_{2}$ concentration than $\mathrm{Fe}_{2} \mathrm{O}_{3} / \mathrm{TiO}_{2} / \mathrm{Al}_{2} \mathrm{O}_{3}$. Steam conversion efficiency initially increased with flow rate of reduced oxygen carrier but at higher rates led to no significant improvement or even to a minor decrease in efficiency. A steam conversion of $65.2 \%$ and $78.6 \%$ was measured for $\mathrm{Fe}_{2} \mathrm{O}_{3} / \mathrm{Al}_{2} \mathrm{O}_{3}$ and $\mathrm{Fe}_{2} \mathrm{O}_{3} / \mathrm{TiO}_{2} / \mathrm{Al}_{2} \mathrm{O}_{3}$ oxygen carriers, respectively. X-ray diffraction was performed on oxygen carriers that were fresh, reduced and partially oxidized in the steam reactor. A final comparison was performed with a conversion of $54.6 \%$ and $64.6 \%$ for $\mathrm{Fe}_{2} \mathrm{O}_{3} / \mathrm{Al}_{2} \mathrm{O}_{3}$ and $\mathrm{Fe}_{2} \mathrm{O}_{3} / \mathrm{TiO}_{2} / \mathrm{Al}_{2} \mathrm{O}_{3}$ oxygen carriers after 49 cycles.

\section{ACKNOWLEDGEMENTS}

This research was supported by Grant MOST 104-3113-E-007-001- from the National Science and Technology Program-Energy, Taiwan.

\section{REFERENCES}

Abad, A., Mattisson, T., Lyngfelt, A., Johansson, M. (2007). The use of iron oxide as oxygen carrier in a chemical-looping reactor. Energy Fuels 86, 1021-1035. https://doi.org/10.1016/j.fuel.200 6.09.021

Adánez, J., Cuadrat, A., Abad, A., Gayán, P., de Diego, L.F., García-Labiano, F. (2010). Ilmenite activation during consecutive redox cycles in chemical-looping combustion. Energy Fuels 24, 1402-1413. https://doi.org/10.1021/ef900856d

Cabello, A., Abad, A., García-Labiano, F., Gayán, P., de Diego, L.F., Adánez, J. (2014). Kinetic determination of a highly reactive impregnated $\mathrm{Fe}_{2} \mathrm{O}_{3} / \mathrm{Al}_{2} \mathrm{O}_{3}$ oxygen carrier for use in gasfueled Chemical Looping Combustion. Chem. Eng. J. 258, 265-280. https://doi.org/10.1016/j.c ej.2014.07.083

Chiu, P.C., Ku, Y., Wu, H.C. Wu, Y.L., Tseng, Y.H., Kuo, Y.L. (2014). Characterization and evaluation of prepared $\mathrm{Fe}_{2} \mathrm{O}_{3} / \mathrm{Al}_{2} \mathrm{O}_{3}$ oxygen carriers for chemical looping process. Aerosol Air Qual. Res. 14, 981-990. https://doi.org/10.4209/aaqr.2013.04.0135

Cho, P., Mattisson, T., Lyngfelt, A. (2006). Defluidization conditions for fluidized-bed of iron, nickel, and manganese oxide containing oxygen-carriers for chemical-looping combustion. Ind. Eng. Chem. Res. 45, 968-977. https://doi.org/10.1021/ie050484d

Cuadrat, A., Abad, A., García-Labiano, F., Gayán, P., de Diego, L.F., Adánez, J. (2011). The use of ilmenite as oxygen-carrier in a 500 Wth Chemical-Looping Coal Combustion unit. Int. J. Greenhouse Gas Control 5, 1630-1642. https://doi.org/10.1016/j.ijggc.2011.09.010

Fan, L.S. (2010). Chemical looping systems for fossil energy conversions. John Wiley \& Sons, Inc. Hurst, S. (1939). Production of hydrogen by the steam-iron method. Oil \& Soap Feb. 
Kierzkowska, A.M., Bohn, C.D., Scott, S.A., Cleeton, J.P., Dennis, J.S., Müller, C.R. (2010). Development of iron oxide carriers for chemical looping combustion using sol-gel. Ind. Eng. Chem. Res. 49, 5383-5391. https://doi.org/10.1021/ie100046f

Li, F.X., Luo, S.W., Sun, Z.C., Bao, X.G., Fan, L.S. (2011). Role of metal oxide support in redox reactions of iron oxide for chemical looping applications: Experiments and density functional theory calculations. Energy Environ. Sci. 4, 3361-3667. https://doi.org/10.1039/c1ee01325d

Lo, M.C. (2011). Composite Fe-Ti based oxygen carrier for chemical looping combustion and hydrogen generation. Master Thesis in Department of Chemical Engineering, National Taiwan University of Science and Technology, Taipei City, Taiwan.

Mattisson, T., Johansson, M., Lyngfelt, A. (2004). Multicycle reduction and oxidation of different types of iron oxide particles - Application to chemical-looping combustion. Energy Fuels 18, 628-637. https://doi.org/10.1021/ef0301405

Sun, S.Z., Zhao, M., Cai, L., Zhang, S., Zeng, D.W., Xiao, R. (2015). Performance of $\mathrm{CeO}_{2}$-modified iron-based oxygen carrier in the chemical looping hydrogen generation process. Energy Fuels 29, 7612-7621. https://doi.org/10.1021/acs.energyfuels.5b01444

Tong, A., Sridhar, D., Sun, Z., Kim, H.R., Zeng, L., Wang, F., Wang, D., Kathe, M.V., Luo, S., Sun, Y., Fan, L.S. (2013). Continuous high purity hydrogen generation from a syngas chemical looping 25 kW th sub-pilot unit with $100 \%$ carbon capture. Fuel 103, 495-505. https://doi.org/10.1016/j. fuel.2012.06.088

Yang, J.B., Cai, N.S., Li, Z.S. (2008). Hydrogen Production from the steam-iron process with direct reduction of iron oxide by chemical looping combustion of coal char. Energy Fuels 22, 25702579. https://doi.org/10.1021/ef800014r

Zhao, Y., Shadman, F. (1990). Kinetics and mechanism of ilmenite reduction with carbon monoxide. AlChE J. 36, 1433-1438. https://doi.org/10.1002/aic.690360917

Zieliński, J., Zglinicka, I., Znak, L., Kaszkur, Z. (2010). Reduction of $\mathrm{Fe}_{2} \mathrm{O}_{3}$ with hydrogen. Appl Catal., A 381, 191-196. https://doi.org/10.1016/j.apcata.2010.04.003 